\title{
Correlations among Perception, Emotion and Behavior in Sustainable Development of Mathematical Creativity Competency of Primary School Students in Vietnam
}

\author{
Quoc-Chung Vu*
}

\author{
Hanoi National University of Education, \\ 136 Xuan Thuy, Dich Vong Hau, \\ Cau Giay, Hanoi, Vietnam \\ "Corresponding author
}

\section{Dieu-Thuy Thi Pham}

Hanoi Pedagogical University 2, 32 Nguyen Van Linh, Xuan Hoa, Phuc Yen, Vinh Phuc, Vietnam

\section{Duy-Cuong Le}

Dong Thap University, 783 Pham Huu Lau, Ward 6, Cao Lanh, Dong Thap, Vietnam

DOI: https://doi.org/10.36941/jesr-2022-0023

\section{Abstract}

Vietnam is currently in the process of renovating the general educational curriculum, shifting from a content-based to a competency-based approach, with mathematical creativity as one of the core competencies. This paper aims to determine the correlations of perception, emotion, and behavior in sustainable development of mathematical creativity for primary school students in Vietnam. Analysis of 5 th graders' survey results in different regions in Vietnam $(N=903)$ shows that perception and emotion are highly correlated with the $p$-value Sig. (2-tailed $)=0.000(<0.01)$; emotion and behavior are also correlated positively with the p-value Sig. (2-tailed) < 0.01, while perception and behavior also have a positive correlation with the p-value Sig. < o.01. From the analysis, there are positive correlations of perception, emotion, and behavior, in which the role of emotion has the strongest effect on the process of teaching mathematical creativity for Vietnamese primary school students. At the same time, the analysis results show that there is no vast difference between students' perception, emotion, and behavior amongst the urban, plain, and mountainous areas in Vietnam. The paper affirms the necessity to discover and strengthen students' mathematical creativity from the primary school levels to equip human resources with essential competencies to face future obstacles in achieving sustainable development.

Keywords: correlation, perception, emotion, behavior, mathematical creativity, sustainable development, primary education 


\section{Introduction}

Mathematics plays an essential part in general education. The content of the subject and its implementation are planned from the $1^{\text {st }}$ grade and continue throughout all the stages of general education in all countries across the world. Mathematics also contributes to the development of core competencies and values for students. Among the mathematics competencies, creativity is both the primary goal and the tool which contributes to the formation and development of other mathematics competencies (Haavold et al., 2020). Especially in today's global context, we have to face increasingly serious problems that have severe impacts on our life including climate change, environmental pollution, depletion of natural resources, new diseases, economic inequality, ethnic and racial discrimination, and terrorism. Such complicated global problems affecting sustainable development can only be resolved by human's creativity.

Creativity is of significance for young children learning mathematics. The emphasis on developing students' creativity right at the primary school level has been greatly paid attention to. With the aspiration that from their first days of schooling, every child will be able to recognize and apply mathematics into the sustainable development process through the simplest and most familiar tasks (Shen \& Edwards, 2017). Consequently, primary school children should be involved in a variety of mathematical tasks to promote their mathematical creativity (Shen \& Edwards, 2017).

In the context of Vietnam, a developing country in Asia, the government has officially commenced an educational renovation program since 2011. The main goals of this reform focus on holistic education for students of general education level, including innovating general education curriculum and textbooks in order to create a fundamental and comprehensive change in the efficacy and quality of general education; integrating knowledge, ethics, and career-oriented instruction; contributing to transforming an education that is heavily based on knowledge to comprehensive development education in both quality and competence, harmonizing virtue, intellect, physicality, beauty and bringing into full play the potential of each student (Vietnam National Assembly, 2014). Most recently, at the UNESCO 2019 Forum on Education Sustainable Development (ESD) organized in Hanoi, Vietnam on 2-3 July, the new orientations in ESD according to the perceptions, emotions and behaviors of learners transitioning from preschool-primary school to high school have been confirmed by the Vietnamese government (Vietnam News, 2019).

In this paper, our research objectives are to identify the scales and achievement levels of perception, emotion and behavior in the mathematical creativity of primary school students in Vietnam towards sustainable development. At the same time, the research findings show the correlations of perception, emotions and behaviors of primary school students in different regions, including mountainous, plain, and urban areas in Vietnam.

There are two research questions, including:

1. What is the level of achievement of the three domains of perception, emotion, behavior in teaching to develop mathematical creativity of grade 5 students towards sustainable development in Vietnam?

2. What is the correlation between the three domains of perception, emotion and behavior?

\section{Literature Review}

\subsection{Creativity and mathematical creativity}

The term 'creativity' has different meanings in different contexts. In other words, there seems to be no universal understanding of what creativity actual means (Wallace, 1986). In the middle of the previous century, Ghiselin (1956) pointed out a definition of creativity from the product perspective. Creativity is the most recent structure of the world of experience, produced by reorganizing the previous world of experience, clearly displaying the creative subject's view of the world and oneself and its connection to that world. Also, in this decade, Kubie (1958) saw creativity as an ability to find 
new relationships. Additionally, Newell et al. (1958) stated that creativity is a problem-solving activity distinguished by originality, non-tradition, tenacity, and perseverance in problem-solving. Similarly, Guilford (1967) defines creativity as a problem-solving process because each problem-solving situation requires individuals to think creatively.

Several decades later witnessed a great number of creativity definitions proposed by scholars. For example, Urban (1995) believed that human creativity is a personality attribute shown in goods that operate in a novel, original, and optimum manner, surprising themselves and others. Moreover, Runco and Chand (1995) gave the structural perspective of creativity and described it as a diverse structure involving two aspects of convergent and divergent thinking, issue discovery and solution, skepticism and confidence. In addition, from the perspective of psychology and education, Villalba (2008) believed that creativity is a thought process that aims to introduce new ideas or new products that are valuable and respectable. Furthermore, Vygotsky (1991, 2004) advocated creative activity to be the highest intellectual activity of human beings and that creativity is a personality attribute, a combination of psychological qualities whereby people based on their knowledge-experience. Consequently, it can be confirmed that although coming from different perspectives, the above authors had the common idea in defining the connotation of the concept of creativity - the core of creativity is to produce something new, either tangible or intangible, to satisfy a particular need of an individual or a society.

Focusing on mathematical creativity, Werdelin (1958) offered a broad definition of mathematical competencies, including aspects of reproduction, creativity, understanding and application, but he mostly focused on creativity in solving math problems. Later, Thorndike (1963) stated that although this competency has no direct meaning for the development of mathematical creative competencies, it is important to practice creative mathematical thinking through solving geometry exercises in various forms. Additionally, Krutetskii (1976) claimed that all the components of his generalized structure had specific mathematical competencies rather than general intellectual competencies that created desirable mathematical capabilities. Most recently, Schoevers et al. (2020) suggest that when promoting students' mathematical creativity, teachers should be aware of mathematical knowledge as well as general creative thinking skills.

Through the analysis of the concepts related creativity described by the above authors for teaching in general and mathematics in particular, the behavioral indicators of creativity for primary school students have the following 10 characteristics:

1. Mastering the knowledge.

2. Having creative and critical thinking.

3. Having intuitive and imaginative ability.

4. Passion for creativity.

5. Perseverance, endurance, overcoming difficulties.

6. Exploring.

7. Investigating and approaching the problems from many points of view.

8. Optimizing the processes and products.

9. Having the ability to quickly transform ways of approaching and thinking.

10. Creating new products.

Furthermore, the math curriculum in Vietnam's new general education curriculum also identifies 5 competencies to be achieved as follows (Table 1 ).

Table 1: Behavioral indicators of required competencies for mathematics education at the primary level

\begin{tabular}{|l|l|}
\hline Competency & Behavioral indicators at the Primary Level \\
\hline $\begin{array}{l}\text { Mathematical thinking } \\
\text { and reasoning }\end{array}$ & $\begin{array}{l}\text { - Perform thinking operations (at a simple level), especially know how to observe, look for } \\
\text { similarities and differences in familiar situations and describe the observation results. } \\
\text { - Outline the evidence, reasoning and make logical arguments before the conclusion. } \\
\text { - Raise and answer the questions when arguing, solving problems. Give evidence and } \\
\text { rational arguments initially before the conclusion. }\end{array}$ \\
\hline
\end{tabular}




\begin{tabular}{|c|c|}
\hline Competency & Behavioral indicators at the Primary Level \\
\hline Mathematical modeling & $\begin{array}{l}\text { - Select the mathematical operations, arithmetic formulas, diagrams, tables, figures to } \\
\text { present, express (say or write) the contents and ideas of the situation appearing in the } \\
\text { simple, practical problem. } \\
\text { - Solve problems arising from the above selection } \\
\text { - Come up with the answer for the situation appearing in practical problem. }\end{array}$ \\
\hline $\begin{array}{l}\text { Mathematical problem } \\
\text { solving }\end{array}$ & $\begin{array}{l}\text { - Identify the problem to be solved and form a question. } \\
\text { - Identify the way to solve the problem. } \\
\text { - Perform and present the way for problem-solving at a simple level. } \\
\text { - Check out the solution. }\end{array}$ \\
\hline $\begin{array}{l}\text { Mathematical } \\
\text { communication }\end{array}$ & $\begin{array}{l}\text { - Listen, comprehend and take notes (summarize) important mathematical information in } \\
\text { documents or informed by other people (at a simple level), thereby identifying the } \\
\text { problems to be solved. } \\
\text { - Present, express (speak or write) ideas, contents, mathematical solutions in interaction } \\
\text { with other people (not yet required to fully and correctly express). Raise and answer } \\
\text { questions when arguing or solving problems. } \\
\text { - Use mathematical language combined with a common language, physical movements to } \\
\text { express mathematical contents in simple situations. } \\
\text { - Show confidence when answering questions, presenting, discussing mathematical } \\
\text { contents in simple situations. }\end{array}$ \\
\hline $\begin{array}{l}\text { Using mathematical } \\
\text { tools and means }\end{array}$ & $\begin{array}{l}\text { - Identify names, effects, specifications of how to preserve simple mathematical tools and } \\
\text { means (calculation sticks, numerical cards, rulers, compasses, ellipses, flat and familiar } \\
\text { shapes, etc.) } \\
\text { - Use mathematical tools and tools to perform simple math learning tasks. } \\
\text { - Familiarize with handheld computers, information technology facilities to support } \\
\text { learning. } \\
\text { - Identify (initially) a number of advantages and limitations of supporting tools and means } \\
\text { for proper use. }\end{array}$ \\
\hline
\end{tabular}

It can be seen that the specific behavioral indicators of the 5 mathematical competencies of primary school students in Vietnam at the creativity level are similar to the 10 characteristics of the creative competencies listed above, with 6 attributes as follows:

1. To identify and understand basic mathematical knowledge systematically and link the knowledge in a logical sequence.

2. Based on visualization, to observe and discover simple mathematical objects and relationships, represent and conceptualize them.

3. To present arguments from some simple evidence so as to conclude, ask questions, and predict some simple transformations; present the process of finding the solution to the problem, and check and comment on the solution.

4. To be amused, curious, constantly observe, discover some simple mathematical relationships, know the value of reason and truth, and be ready to see everything from the perspective of others.

5. To know how to present solutions in different ways, make comments and compare the solutions.

6. To give different solutions to a problem, analyze and compare those solutions, propose similar problems or problems in new situations with practical application, and respect friends' opinions on how to solve the problems while discussing.

2.2 Factors related to teaching to develop mathematical creativity of primary school students in Vietnam for sustainable development goals

The associated literature identifies a number of factors influencing the innovation of mathematical creativity teaching. For example, the theory of the components of creativity proposed by (Amabile, 1983) 
consists of two important components: the creative subject and the creative environment. The theory highlights that the social environment can positively or negatively affect creativity. Consequently, Amabile (1983) affirmed that the environment could affect the creative motivation of students and workers.

The school's educational environment is an objective factor that directly affects the students' creativity in learning activities. Specifically, there are factors in the educational environment that affect students' creativity, including:

Peers' influence: Organizing the same grade of education classroom to facilitate creativity better than that with multi-grade students (Drews et al., 1961).

Character traits and behaviors of teachers: Teacher attitudes can lead to student's creativity (Deci et al., 1981).

The general atmosphere in the classroom: Open classroom environment facilitates creativity more effectively than the traditional environment (Haddon \& Lytton, 1968).

It can be observed that the above environmental factors (school environment, social environment) have a comprehensive impact on each student in the learning process.

The following research on creativity and the factors affecting the creativity of learners in general and primary school students in particular show that creativity is influenced by the combined impact of the individual learner factors and learning environment. This is the basis for identifying the scope of the survey of mathematical creativity of $5^{\text {th }}$ graders in Vietnam.

2.3 Perception, emotion, and behavior in teaching to develop mathematical creativity of primary school students for sustainable development goals

Perception, emotion and behavior play a crucial role in teaching to develop mathematical creativity for children. These factors influence the relationship between the two structures of mathematical creativity and mathematical ability (Kattou et al., 2013). Specifically, focusing on genders, Salihu et al. (2018) showed that gender differences and general background variables had little effect on mathematics achievement, but living environment and socioeconomic status have a significant impact on children's math performance. Additionally, Jindal-Snape et al. (2013) researched and reviewed 210 studies from 2005 - 2011 related to creative environment for students' learning at school. Their findings may help educational managers, teachers, and stakeholders to be aware of the impact of the creative environment on children's academic success in the future.

Regarding factors affecting mathematical creativity, Salihu et al. (2018) emphasized cognitive aspects and even more so on emotional factors in their findings. Furthermore, Haylock (1987) focused on evaluating two main aspects related to mathematical creativity: the capacity to break out from fixations when solving mathematical problems, as well as the ability to produce divergently in mathematical circumstances. Similarly, Levenson (2011) determined the correlation between collective learning activities in mathematics and mathematical creativity, thereby creating a concept: collective mathematical creativity in primary school classes. Notably, Akgul and Kahveci (2018) conducted a study on the Mathematics Creativity Scale for junior high school students aged 10 - 15 years old. A mathematical creativity scale was developed by assessing students' responses for fluency, adaptability, and originality as variables influencing creativity. Mann (2005) also stated that it is critical to identify kids as early as possible and design a mathematics curriculum to help them reach their full potential.

For perception, emotion and behavior in mathematical creativity development, Joo et al. (2019) have found that these aspects of learners are directly related to academic achievement. However, Xenofontos (2019) argued that before planning and implementing curriculum reform professional development programs, it is necessary to discuss teachers' on the reform of primary school math education curriculum to collect their ideas and feedback, especially the comments of experienced teachers.

The current study also examines factors affecting the learning process of primary school students, especially the influence of Confucianism on education in Vietnam. Therefore, the content of the survey in this study mentioned impacts from the perspective of culture and family tradition. Based on the analysis of research results directly related to the factors that influence the creativity of 
learners in many different countries and stages, a number of factors directly related to the creativity of primary school students for sustainable development are shown in Table 2.

Table 2: Summary and analysis of research work on the impact factors related to the components of creativity

\begin{tabular}{|c|c|c|c|c|}
\hline \multirow[t]{2}{*}{ Impact factors } & \multirow[t]{2}{*}{$\begin{array}{l}\text { The components of creativity that } \\
\text { are related to the impact factor }\end{array}$} & \multicolumn{3}{|c|}{$\begin{array}{l}\text { The level and meaning of the } \\
\text { relationship }\end{array}$} \\
\hline & & \begin{tabular}{|l|} 
Positive \\
impact
\end{tabular} & $\begin{array}{l}\text { Little to } \\
\text { no impact }\end{array}$ & $\begin{array}{l}\text { Negative } \\
\text { impact }\end{array}$ \\
\hline Emotion, perception & Learning outcomes & $\mathrm{x}$ & & \\
\hline Attitude; character & Creative emotions & $\mathrm{x}$ & & \\
\hline Courage; spirit & $\begin{array}{l}\text { To be able to have creative solutions } \\
\text { and solve problems in many ways }\end{array}$ & $\mathrm{x}$ & & \\
\hline Experience & Faith, attitude and creative emotion & $\mathrm{x}$ & & \\
\hline Gender - Learning process & Creative belief & & $\mathrm{x}$ & \\
\hline Thinking - Discovery & The meaning of the created & $\mathrm{x}$ & & \\
\hline Self-assessment & Managing the creative process & $\mathrm{x}$ & & \\
\hline $\begin{array}{l}\text { Interact and share in group } \\
\text { activities }\end{array}$ & Ideas and creative products & $\mathrm{x}$ & & \\
\hline Mathematics ability & Creativity in mathematics & $\mathrm{x}$ & & \\
\hline Use learning games & \begin{tabular}{|l|} 
Motivation and thinking \\
development, creative activity skills
\end{tabular} & $\mathrm{x}$ & & \\
\hline Age - The learning stages & $\begin{array}{l}\text { Awareness of creative environment } \\
\text { on children's academic success in the } \\
\text { future. }\end{array}$ & $\mathrm{x}$ & & \\
\hline Self-management & Creative motivation & $\mathrm{x}$ & & \\
\hline Fluency; flexibility, originality & $\begin{array}{l}\text { Interaction of } 3 \text { elements: fluency, } \\
\text { flexibility and originality }\end{array}$ & $\mathrm{x}$ & & \\
\hline Behavior & The degree of impact on creativity & $\mathrm{x}$ & & \\
\hline Reading culture & Learning outcomes & $\mathrm{x}$ & & \\
\hline $\begin{array}{l}\text { Task authenticity - Problem- } \\
\text { solving efficacy and } \\
\text { satisfaction. }\end{array}$ & Academic achievement & $\mathrm{x}$ & & \\
\hline Study plan & Creative emotions and behaviors & $\mathrm{x}$ & & \\
\hline Student autonomy & Learning outcomes & $\mathrm{x}$ & & \\
\hline Cultural awareness & Academic achievement & $\mathrm{x}$ & & \\
\hline $\begin{array}{l}\text { Readiness to face challenges } \\
\text { in learning and life. }\end{array}$ & Creative situation & $\mathrm{x}$ & & \\
\hline
\end{tabular}

From Table 2, the environmental and living conditions of students are categorized into groups: mountainous, plain and urban. The components of mathematical creativity of primary school students are grouped into 3 areas: perception, emotion and behavior. The data of the three regions and the three domains will be the basis to design the survey questionnaire as well as a scale to evaluate the achieved levels of the above contents.

\section{Methods}

\subsection{Data sources}

The survey was designed with 3 sections: perception, emotion and behavior. Each questionnaire consists of 10 questions on applying mathematical knowledge in grade 5 to solve the problems of sustainable development. The questions are used to provide data sources to determine the 
correlation between the three perceptual, emotional, and behavior domains of primary school students' creativity for sustainable development in Vietnam. Questions were discussed many times with students and teachers in different regions in Vietnam to ensure the suitability of content and appropriate wordings.

It is important to note that Vietnam is a multi-ethnic and multi-religion country with different characteristics of lifestyle, culture, socio-economic conditions, etc. in each region. Consequently, the survey questionnaires for grade 5 students were implemented in all three regions: urban, rural, and mountainous areas in 14 provinces and cities, including the North, the Central and the South. These fourteen cities and provinces represent the most distinct general features of the three regions in Vietnam. In addition, information collected from conversations with teachers, primary school administrators and parents from these provinces is also a data source to design the survey questionnaires.

The questions in the survey include closed-ended and open-ended questions based on a 5-point Likert scale. To reduce neutral answers, the survey questions use only the following 4 levels:

Questions about perception have 4 levels: 1. Strongly disagree, 2. Disagree, 3. Agree, 4. Strongly agree. Whereas, questions about emotions have 4 levels: 1. Not interested at all, 2. Not very interested, 3. Interested, 4. Very interested. Questions about behavior have 4 levels: 1. Never, 2. Rarely, 3. Occasionally, 4. Regularly.

\subsection{Data collection}

The questionnaires were designed to be used in the survey in 2 phases. In the phase 1 , the survey questionnaire were piloted to test the reliability, feasibility and validity. In the phase 2 , the official surveys were distributed to potential participants after the questionnaire content was modified.

To carry out the first phase, we surveyed 50 randomly selected 5 th graders at West Hanoi multilevel private school to test the structure, content and wording of each item as well as the whole set of questions in each domain. Some questions have been revised so that $5^{\text {th }}$ graders can clearly understand and identify the meaning of each question.

In phase 2, with the updated and revised questionnaires, we conducted surveys at a number of primary schools in 14 provinces and cities across the country that represent the regional characteristics of the three regions in Vietnam. The total number of 5 th graders surveyed was 903 in all 3 urban, plain, and mountainous areas of the North, Central and South of Vietnam. During the data collection process, we discussed the purpose, content, and how to conduct the survey in advance with the teachers and principals of surveyed primary schools. Some parents also participated in the discussion regarding the survey questions.

\subsection{Sampling}

A total of 903 students aged 10 to 11 years old in the $5^{\text {th }}$ grade participated in the official survey. Students from public and private primary schools were randomly selected in 14 provinces and cities. The majority of students in the survey come from public schools. It is important to note that both public and private schools in Vietnam implement the similar national curriculum. With the diversity in customs, culture, and living environment of the students participating in the survey, students' experiences in solving sustainability issues are very different. This has informed the researchers on how to design the questions in the survey to cover all participants' needs and experiences.

\subsection{Data analysis}

Student responses - chosen answers for questions in the questionnaire - provided us with the raw data sources that were then processed and evaluated using SPSS software. The SPSS software was used to find the Pearson correlation between the three domains of perception, emotion, and behavior 
in teaching mathematical creativity for primary students. The data from the student's questionnaire were used as the primary data source, which could then be checked from the information provided teachers, primary school administrators and parents from different provinces during the survey implementation.

The process of data analysis is as follows: First, a detailed descriptive analysis of the data collected was conducted. The analysis shows the mean and range for the variables. Then, the descriptive analysis was presented to and discussed thoroughly with other experts, in order to ensure data validity and result reliability related to the correlation between the three domains of perception, emotion, and behavior in teaching mathematical creativity for primary school students in Vietnam for sustainable development. This also led to a discussion about the meaning of teaching mathematical creativity for primary school students in Vietnam. Finally, the correlations were computed.

The findings are presented through the data analysis of mean and standard deviation (SD) values of the three domains of perception, emotion, and behavior. The analysis results also show the correlation between the three areas of perception, emotion, and behavior in teaching mathematical creativity for grade 5 students in Vietnam for sustainable development. At the same time, the study uses analysis of variance (ANOVA) to compare the differences in perceptions, emotions and behaviors in urban, plan, and mountainous areas.

\section{Findings}

The scale of 10 perception questions has a Cronbach's Alpha of o.6o9, the scale of emotion with 10 questions has a Cronbach's Alpha of 0.650, and the behavior scale with 10 questions has a reliability value of 0.61 . These reliability values are not high but acceptable because these are relatively new concepts to the subject of the study.

\subsection{The first research question}

First of all, the scale of Perception includes 3 factors: School, Family and Society (Appendix A). The School factor has mean value of 2.78 and $S D=0.54$; the Family factor has mean value of 2.91 and $S D=$ 0.76 ; and the Society factor has mean value of 2.90 and $\mathrm{SD}=1.04$. It can be seen that all these 3 groups have a fair perception level with similar mean values, in which the Society factor has a large SD which shows that the responses are highly dispersed and inconsistent. This is also an appropriate reflection because students can easily perceive social factors through activities such as observation, watching TV, reading newspapers, the internet, etc. The Society factor has a significant impact on students' perception in everyday life.

In the School factor, the question/item or has a low Mean which indicates a disagreement; the item 03 has the highest "Agree" level with Mean $=2.95$ and SD $=1$. Through analyzing the content of mathematics curriculum and textbooks in Vietnam today, it can be seen that teaching mathematical creativity for sustainable development remains largely insufficient. At the same time, through the observation of in-class teaching and discussion with teachers, the researchers realized that the integration of mathematical content and knowledge into solving sustainable development issues has not been implemented by many teachers. This may greatly affect the teaching of mathematical creativity for primary school students in Vietnam for sustainable development.

Of the 10 survey questions, the Family factor with its 3 questions showed a high level of agreement. The Social factor (with 2 questions) also has a relatively high level of agreement. Thus, the students' perception of creativity in Mathematics education for sustainable development goal is relatively high with a mean of 2.85 and SD of 0.54 .

Second, in the survey for the domain of Emotion, there are also 3 factors for the scale: School, Family and Society (Appendix B). The School factor has mean $=2.82$ and SD $=0.52$; the Family factor has mean $=2.84$ and $\mathrm{SD}=0.61$; and the Society factor has mean $=2.73$ and $\mathrm{SD}=0.70$. All these 3 
groups have a fair emotion level with similar mean values. In the School factor, the item o1 has a lower mean than the others, although still at "Interested" level. The Family factor has a relatively high level of interest and the means are roughly similar for all the three questions. The Society factor also shows a high level of Interest. Thus, the students' emotion for creativity in Mathematics education for sustainable development is at a high level with mean of 2.81 and SD of 0.45 .

The survey results show that the domain of Emotion has a relatively strong impact on the teaching to develop mathematical creativity of primary school students in Vietnam for sustainable development. When students express an interest (emotion), they will spend more time researching, and investigating problems to learn and find solutions (behaviors) to solve problems. As a result, students develop mathematical creativity for themselves.

Third, in the survey for the domain of Behavior, the scale also includes 3 factors: School, Family and Society (Appendix C). The School factor has mean $=2.72$ and $\mathrm{SD}=0.55$; the Family factor has mean $=2.61$ and $\mathrm{SD}=0.65$; and the Society factor has mean $=2.51$ and $\mathrm{SD}=0.81$. All these 3 groups have a fairly high behavior level with roughly similar mean values, in which Society factor is the lowest. In the School factor, the behavior of item 02 occasionally takes place. In the Family factor that consists of 3 out of the 10 questions, the item o8 show that students rarely apply knowledge in this manner; likewise, for the Social factor item 10. Thus, although some behaviors are rare, the students' behavior of creativity in learning Math for sustainable development is at an acceptable level with Mean of 2.65 and SD of 0.47 .

\subsection{The second research question}

The research results reveal that there exists a correlation between three domains of perception, emotion and behavior in teaching to develop mathematical creativity for primary school students in Vietnam for sustainable development (Table 3). Through analysis we found the following correlation: First, Pearson correlation coefficient ( $r$ ) shows that Perception and Emotion have a positive correlation, and there is a strong correlation with the value of Sig (2-tailed) $=0.000(<0.01)$, which means that the positive correlation is statistically significant and accurate with $99 \%$ of the population. This shows that students with good perception also have good emotion about the Creativity in their Mathematics learning process for sustainable development.

Second, the correlation table also shows the positive correlation between Emotion and Behavior with the value of Sig (2-tailed) <0.01. However, the Pearson correlation coefficient suggests that this correlation has a comparatively lower degree of 'tightness' than Perception and Emotion.

Third, the correlation value of Perception and Behavior also has positive correlation with the pvalue <o.ol. This shows that students' Perception, Emotion and Behavior of creativity in the Mathematics learning process for sustainable development are correlated with one another, and this correlation is relatively high and proportional to one another.

Table 3: Correlations

\begin{tabular}{|l|l|c|c|c|}
\hline \multicolumn{2}{|l|}{ Factors } & Perception & Emotion & Behavior \\
\hline \multirow{4}{*}{ Perception } & Pearson Correlation & 1 & $0.563^{* *}$ & $0.350^{* *}$ \\
\cline { 2 - 5 } & Sig. (2-tailed) & & 0.000 & 0.000 \\
\cline { 2 - 5 } & $\mathrm{N}$ & 903 & 903 & 903 \\
\hline \multirow{3}{*}{ Emotion } & Pearson Correlation & $0.563^{* *}$ & 1 & $0.452^{* *}$ \\
\cline { 2 - 5 } & Sig. (2-tailed) & .000 & & 0.000 \\
\cline { 2 - 5 } & $\mathrm{N}$ & 903 & 903 & 903 \\
\hline \multirow{3}{*}{ Behavior } & Pearson Correlation & $0.350^{* *}$ & $0.42^{* *}$ & 1 \\
\cline { 2 - 5 } & Sig. (2-tailed) & 0.000 & 0.000 & 903 \\
\cline { 2 - 5 } & $\mathrm{N}$ & 903 & 903 & \\
\hline
\end{tabular}

**. Correlation is significant at the o.or level (2-tailed). 
The differences of perception, emotion and behavior according to school locations are described in Figure 1.

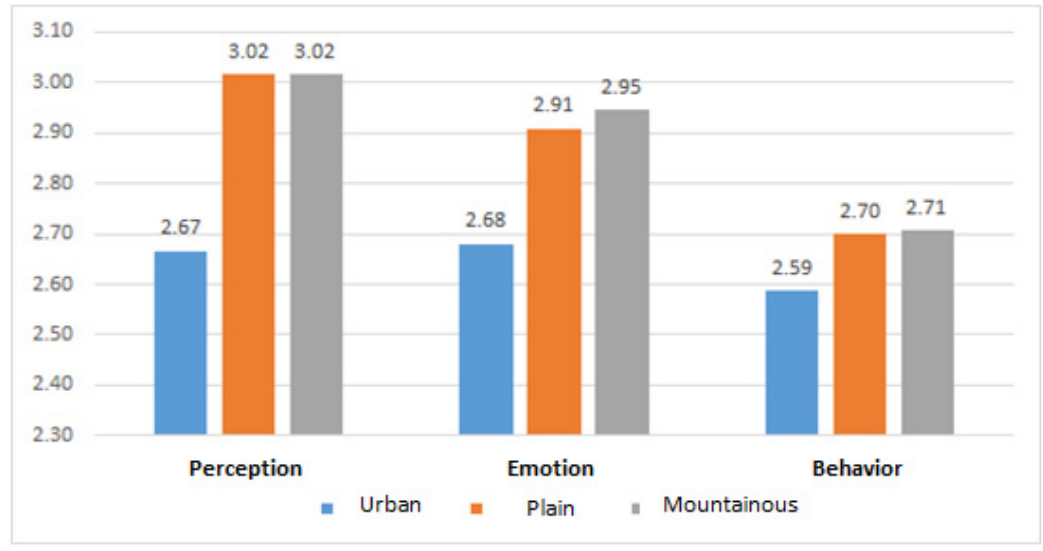

Figure 1: Perception, emotion and behavior of students in different regions

As shown in Figure 1, the Perceptions, Emotions, and Behaviors of schools in the Plain and Mountainous Regions have roughly similar Means in a fair range, whereas in the urban area, the Mean values are at a low level of fair value and much lower than those of other regions. The ANOVA test results show that the differences in Perception, Emotion and Behavior among Urban, Plain and Mountain groups are statistically significant (Table 4).

The results of the data analysis reflect the current situation in Vietnam, in which the students in urban areas have many advantages in terms of facilities, better means and access to information. However, they may be subjected to over-protective or over-solicitous parenting, which in turn deny them the experiences necessary to cope with the current sustainable development issues. On the contrary, students in the plains and mountainous areas are often faced with sustainability issues like poverty, disease, natural disasters, etc. Therefore, they pay more attention to issues that occur in their lives, making them much more aware of sustainable development than their urban counterparts.

Table 4: ANOVA

\begin{tabular}{|l|l|c|c|c|c|c|}
\hline \multicolumn{2}{|c|}{} & Sum of Squares & Df & Mean Square & F & Sig. \\
\hline \multirow{4}{*}{ Perception } & Between Groups & 27.706 & 2 & 13.853 & 53.731 & .000 \\
\cline { 2 - 7 } & Within Groups & 232.038 & 900 & .258 & & \\
\cline { 2 - 7 } & Total & 259.743 & 902 & & & \\
\hline \multirow{3}{*}{ Emotion } & Between Groups & 14.290 & 2 & 7.145 & 37.811 & .000 \\
\cline { 2 - 7 } & Within Groups & 170.069 & 900 & .189 & & \\
\cline { 2 - 7 } & Total & 184.359 & 902 & & & \\
\hline \multirow{3}{*}{ Behavior } & Between Groups & 3.067 & 2 & 1.534 & 7.116 & .001 \\
\cline { 2 - 7 } & Within Groups & 193.961 & 900 & .216 & & \\
\cline { 2 - 7 } & Total & 197.028 & 902 & & & \\
\hline
\end{tabular}

The Mean values of school, family and society factors show that in the school factor, the Perception, Emotion and Behavior of Urban students have lower Mean values than those of the Plains and Mountainous; for the Plains and the Mountainous, there is only a little difference in Mean values (Table 5). 
Table 5: Means and Standard Deviations

\begin{tabular}{|l|l|l|c|c|c|c|c|}
\hline \multicolumn{2}{|c|}{} & \multicolumn{2}{|c|}{ School } & \multicolumn{2}{c|}{ Family } & \multicolumn{2}{c|}{ Society } \\
\cline { 3 - 8 } \multicolumn{2}{|c|}{} & Mean & Std. Deviation & Mean & Std. Deviation & Mean & Std. Deviation \\
\hline \multirow{3}{*}{ Perception } & Urban & 2.63 & 0.52 & 2.69 & 0.65 & 2.71 & 0.71 \\
\cline { 2 - 8 } & Plains & 2.89 & 0.50 & 3.16 & 0.68 & 3.11 & 0.71 \\
\cline { 2 - 8 } & Mountainous & 2.95 & 0.55 & 3.06 & 0.61 & 2.94 & 0.75 \\
\hline \multirow{3}{*}{ Emotion } & Urban & 2.68 & 0.50 & 2.72 & 0.61 & 2.61 & 0.69 \\
\cline { 2 - 8 } & Plains & 2.92 & 0.50 & 2.94 & 0.59 & 2.84 & 0.65 \\
\cline { 2 - 8 } & Mountainous & 2.98 & 0.50 & 2.95 & 0.59 & 2.84 & 0.72 \\
\hline \multirow{3}{*}{ Behavior } & Urban & 2.64 & 0.50 & 2.51 & 0.61 & 2.56 & 0.76 \\
\cline { 2 - 8 } & Plains & 2.81 & 0.53 & 2.78 & 0.65 & 2.30 & 0.87 \\
\cline { 2 - 8 } & Mountainous & 2.78 & 0.62 & 2.65 & 0.69 & 2.59 & 0.83 \\
\hline
\end{tabular}

In summary, students' responses show that Grade 5 students' Perception, Emotion, and Behavior in teaching Mathematical Creativity for sustainable development in Vietnam are fairly good in all factors of School, Family and Society, with a moderate positive correlation.

\section{Discussion and Conclusion}

Mathematics helps us to make sense of the world around us. The studies of mathematical creativity have good implications for the ways in which teachers can foster creative thinking in the mathematics classroom (Kandemir et al., 2019; Young, 2021). The current study showed that mathematical creativity plays a significant part in realizing the goal of sustainable development in Vietnam. Through this research, we find that it is necessary to detect and foster early the mathematical creativity for primary school students. This study also contributes materials related to the correlation between the three domains of perception, emotion and behavior of $5^{\text {th }}$ graders in teaching mathematical creativity for sustainable development.

There are things teachers may do in their classrooms to encourage mathematical innovation. They explicitly related creativity to everyday life and emphasized the significance of utilizing realworld examples to encourage creativity in mathematics (Panaoura \& Panaoura, 2014). Our research focuses on the correlation between perception, emotion, and behavior in teaching mathematical creativity for grade 5 students in Vietnam. Through the perspectives of perception, emotion and behavior, the most significant findings of the survey have shown that mathematical creativity can be taught to grade 5 students in Vietnam. In particular, the survey results and data analysis show that $5^{\text {th }}$ graders in Vietnam are aware of the need to develop mathematical creativity for sustainable development. Students are even able to perform behaviors according to the emotions they feel through daily influences in life, books, television, the Internet, etc. However, students are not fully aware of and lack knowledge about some school and social factors.

For young children learning mathematics, creativity is essential. However, according to a large body of evidence, teachers in the classroom do not sufficiently promote creativity in the acquisition of mathematics for young children (Shen \& Edwards, 2017). The findings of this research show that the domains of Perception, Emotion and Behavior in teaching to develop mathematical creativity of grade 5 students are highly and positively correlated, in which the correlation between Perception and Emotion is highest (o.56) with Sig (2-tailed) $=0.000(<0.01)$; Emotions and Behavior have a positive correlation with the value of Sig (2-tailed) <0.o1; Perception and Behavior have a positive correlation at the lowest (0.35) with the test value <0.01. At the same time, the ANOVA test values show that Perception, Emotion and Behavior in Urban, Plain and Mountainous regions have approximately the same Mean values and are in fair range. In urban areas, the Mean values are lower than those in the Plain and Mountainous Regions. This shows that the developing mathematical creativity for Vietnamese primary children is noted in all areas and regions in Vietnam. This is a good sign because the gaps in learning content, learning environment, and learning outcomes of cities, 
plains and mountainous areas are getting smaller.

With the above findings, this research is also likely to support the proposal of developing mathematical creativity for primary school students in Vietnam by designing the content of teaching mathematics in textbooks, as well as changes in teaching methods towards practicality. The development of mathematics textbooks and teaching methods should also consider molding the perception, emotion and behavior of students toward achieving sustainable development goals. The provided research findings may serve as practical valuable suggestions for educational administrators and teachers to adjust, and supplement necessary contents to implement renovation in Mathematics education in Vietnam for the present, as well as in the future.

\section{References}

Akgul, S., \& Kahveci, N. G. (2018). A Study on the Development of Abhisekha Ritual. The Journal of Indian Philosophy, 54, 93-122. https://doi.org/10.32761/kjip.2018..54.004

Amabile, T. M. (1983). The social psychology of creativity: A componential conceptualization. Ournal of Personality and Social Psychology, 45(2), 357-376. https://doi.org/10.1037/oo22-3514.45.2.357

Deci, E. L., Schwartz, A. J., Sheinman, L., \& Ryan, R. M. (1981). An instrument to assess adults' orientations toward control versus autonomy with children: Reflections on intrinsic motivation and perceived competence. Journal of Educational Psychology, 73(5), 642-65o. https://doi.org/10.1037/0022-0663.73.5.642

Drews, E. M., Bish, C. E., Cotlove, E., \& Hitchcock, A. A. (1961). Guidance for the academically talented student: Report of a conference sponsored jointly by the American Personnel and Guidance Association and the National Education Association Project on the Academically Talented Student. National Education Association. https://doi.org/10.1037/13150-ooo

Ghiselin, B. (1956). The creative process and its relation to the identification of creative talent. In The 1955 University of Utah research conference on the identification of creative scientific talent (pp. 195-203). University of Utah Press.

Guilford, J. P. (1967). Creativity: yesterday, today and tomorrow. The Journal of Creative Behavior, 1(1), 3-14. https://doi.org/https://doi.org/10.1002/j.2162-6057.1967.tboooo2.x

Haavold, P., Sriraman, B., \& Lee, K. H. (2020). Creativity in mathematics education. In L. S (Ed.), Encyclopedia of Mathematics Education. Springer. https://doi.org/10.1007/978-3-030-15789-0_33

Haddon, F. A., \& Lytton, H. (1968). Teaching approach and the development of divergent thinking abilities in primary schools. British Journal of Educational Psychology, 38(2), 171-180. https://doi.org/10.111/j.2044-8279.1968.tbo2002.x

Haylock, D. W. (1987). A framework for assessing mathematical creativity in school chilren. Educational Studies in Mathematics, 18(1), 59-74. https://doi.org/10.1007/BFoo367914

Jindal-Snape, D., Davies, D., Collier, C., Howe, A., Digby, R., \& Hay, P. (2013). The impact of creative learning environments on learners: A systematic literature review. Improving Schools, 16(1), 21-31. https://doi.org/10.1177/1365480213478461

Joo, Y. J., Lim, K. Y., \& Lee, S. Y. (2019). Project-based learning in capstone design courses for engineering students: Factors affecting outcomes. Issues in Educational Research, 29(1), 123-140.

Kandemir, M. A., Tezci, E., Shelley, M., \& Demirli, C. (2019). Measurement of creative teaching in mathematics class. Creativity Research Journal, 31(3), 272-283. https://doi.org/10.1080/10400419.2019.1641677

Kattou, M., Kontoyianni, K., Pitta-Pantazi, D., \& Christou, C. (2013). Connecting mathematical creativity to mathematical ability. ZDM - International Journal on Mathematics Education, 45(2), 167-181. https://doi.org/10.1007/s11858-012-0467-1

Krutetskii, V. A. (1976). The psychology of mathematical abilities in schoolchildren. University Of Chicago Press.

Kubie, L. S. (1958). Neurotic distortion of the creative process. University of Kansas Press.

Levenson, E. (2011). Exploring collective mathematical creativity in elementary school. Journal of Creative Behavior, 45(3), 215-234. https://doi.org/10.1002/j.2162-6057.2011.tbo1428.x

Mann, E. L. (2005). Mathematical creativity and school mathematics: Indicators of mathematical creativity in middle school students. http://www.fisme.science.uu.nl/publicaties/literatuur/2005_mann_creativity.pdf

Newell, A., Shaw, J. C., \& Simon, H. A. (1958). The processes of creative thinking. The Rand Corporation. http://shelfi.library.cmu.edu/IMLS/MindModels/creativethinking.pdf

Panaoura, A., \& Panaoura, G. (2014). Teachers' awareness of creativity in mathematical teaching and their practice. IUMPST: The Journal, 4(June), 1-11. 
Runco, M. A., \& Chand, I. (1995). Cognition and creativity. Educational Psychology Review, 7, $243-267$. https://doi.org/10.1007/BFo2213373

Salihu, L., Aro, M., \& Räsänen, P. (2018). Children with learning difficulties in mathematics: Relating mathematics skills and reading comprehension. Issues in Educational Research, 28(4), $1024-1038$. http://www.iier.org.au/iier28/salihu.pdf

Schoevers, E. M., Kroesbergen, E. H., \& Kattou, M. (2020). Mathematical creativity: A combination of domaingeneral creative and domain-specific mathematical skills. Journal of Creative Behavior, 54(2), $242-252$. https://doi.org/10.1002/jocb.361

Shen, Y., \& Edwards, C. P. (2017). Mathematical creativity for the youngest school children: Kindergarten to third grade teachers' interpretations of what it is and how to promote it. Mathematics Enthusiast, 14(1), 325-346.

Thorndike, R. L. (1963). The measurement of creativity. Teachers College Record, 64(5), 422-424.

Urban, K. (1995). Creativity: A componential approach. In The post conference China meeting of the 11th world conference on gifted and talented children.

Vietnam National Assembly. (2014). Resolution 88/2014/2014 on Renovation of curricula and textbooks for general education. http://vbpl.vn/bogiaoducdaotao/Pages/vbpq-van-ban-goc.aspx?ItemID=144398

Vietnam News. (2019, July 3). UNESCO 2019 Forum on Education for Sustainable Development and Global Citizens opens in Hà Nội. https://vietnamnews.vn/society/522147/unesco-2019-forum-on-education-for-sustainabledevelopment-and-global-citizens-opens-in-ha-noi.html

Villalba, G. E. (2008). On creativity: Towards an understanding of creativity and its measurements. OPOCE. https://publications.jrc.ec.europa.eu/repository/handle/JRC48604

Vygotsky, L. S. (1991). Imagination and creativity in the adolescent. Soviet Psychology, $29(1), 73-88$. https://doi.org/10.2753/RPO1061-0405290173

Vygotsky, L. S. (2004). Imagination and creativity in childhood. Journal of Russian E East European Psychology, 42(1), 7-97. https://doi.org/10.108o/10610405.2004.11059210

Wallace, B. (1986). Creativity: Some definitions: the creative personality; the creative process; the creative classroom. Gifted Education International, 4(2), 68-73. https://doi.org/10.1177/026142948600400202

Werdelin, I. (1958). The mathematical ability: Experimental and factorial studies. C W K Gleerup/Ejnar Munksgaard.

Xenofontos, C. (2019). Primary teachers' perspectives on mathematics during curriculum reform: A collective case study from Cyprus. Issues in Educational Research, 29(3), 979-996.

Young, J. (2021). Fostering mathematical creativity. Learning to Teach, 10(1), 102-110.

\section{Appendix A: Survey Questions for the Domain of Perception for 5th Grade Students}

This survey seeks to investigate the correlation of Perception, Emotion and Behavior in teaching for the sustainable development of mathematical creativity of primary school students in Vietnam. Please circle the number that best represents your on-the-spot belief about each statement based on the corresponding scale below.

Corresponding scale: Perception; 1. Strongly disagree, 2. Disagree, 3. Agree, 4. Strongly agree

\begin{tabular}{|c|c|c|c|c|c|c|}
\hline Factor & Question & Survey Question & Indicator & & ve & \\
\hline \multirow{5}{*}{ School } & Question 1 & $\begin{array}{l}\text { When observing the statistical chart and the percentage, do you agree that it is } \\
\text { possible to recognize the state of malnutrition or obesity of your classmates? }\end{array}$ & Perception & 12 & & 4 \\
\hline & Question 2 & $\begin{array}{l}\text { Do you agree that you and your classmates can use a measuring ruler to determine } \\
\text { the appropriate seat for classmates with visual impairments? }\end{array}$ & Perception & & & 4 \\
\hline & Question 3 & $\begin{array}{l}\text { Do you agree that learning about velocity, distance and time can help you figure out } \\
\text { how to calculate a reasonable path to the school? }\end{array}$ & Perception & $1 \mid 2$ & & 4 \\
\hline & Question 4 & $\begin{array}{l}\text { Do you agree that the knowledge of geometry can help you arrange tables and chairs } \\
\text { in your classrooms in a neat and beautiful order? }\end{array}$ & Perception & & & $1^{4}$ \\
\hline & Question 5 & $\begin{array}{l}\text { When studying geometry and measuring quantities, you need to compare the } \\
\text { similarities and differences in the shapes of objects in the class and in your family } \\
\text { with the shapes you have learned. } \\
\text { Do you agree with this idea? }\end{array}$ & Perception & & & 4 \\
\hline \multirow[t]{2}{*}{ Family } & Question 6 & $\begin{array}{l}\text { It is necessary to use knowledge of percentages and mathematical statistics to calculate } \\
\text { saving on electricity, water, gas, etc., in your family. } \\
\text { Do you agree with this idea? }\end{array}$ & Perception & & & 4 \\
\hline & Question 7 & Do you agree that it is necessary to track the use of money to save daily expenses? & Perception & & & \\
\hline
\end{tabular}




\begin{tabular}{|l|l|l|l|l|l|l|l|}
\hline Factor & Question & \multicolumn{1}{|c|}{ Survey Question } & \multicolumn{1}{|c|}{ Indicator } & \multicolumn{1}{|c|}{ Level } \\
\hline & Question 8 & $\begin{array}{l}\text { If you use statistical knowledge and percentage to calculate electricity savings, do } \\
\text { you agree that you can also use that knowledge to calculate water and gas savings? }\end{array}$ & Perception & 1 & 2 & 3 & 4 \\
\hline \multirow{2}{*}{ Society } & Question 9 & $\begin{array}{l}\text { Mathematical knowledge of statistics, calculation, measurement, etc., can be applied } \\
\text { to build roads, sewers, parks, memorial houses in communes, wards, villages. Do you } \\
\text { agree? }\end{array}$ & Perception & 1 & 2 & 3 & 4 \\
\cline { 2 - 7 } & $\begin{array}{l}\text { Question } \\
\text { 10 }\end{array}$ & $\begin{array}{l}\text { Math statistics and percentages can be applied for population census to gather } \\
\text { information about gender, employment, income level, etc., in communes, wards, } \\
\text { villages and hamlets. Do you agree? }\end{array}$ & Perception & 1 & 2 & 3 & 4 \\
\hline
\end{tabular}

\section{Appendix B: Survey Questions for the Domain of Emotion for 5th Grade Students}

This survey seeks to investigate the correlation of Perception, Emotion and Behavior in teaching for the sustainable development of mathematical creativity of primary school students in Vietnam. Please circle the number that best represents your on-the-spot belief about each statement based on the corresponding scale below.

Corresponding scale: Emotion; 1. Not interested at all, 2. Not very interested, 3. Interested, 4. Very interested

\begin{tabular}{|c|c|c|c|c|c|}
\hline Factor & Question & Survey Question & Indicator & & evel \\
\hline \multirow{5}{*}{ School } & Question 1 & $\begin{array}{l}\text { What do you think when you look at the chart to see the malnutrition or obesity } \\
\text { status of your classmates, do you know how to prevent it? }\end{array}$ & Emotion & 12 & 34 \\
\hline & Question 2 & $\begin{array}{l}\text { Would you be interested in discussing with your classmates about measuring to } \\
\text { determine appropriate seat for classmates with visual impairment? }\end{array}$ & Emotion & 12 & 34 \\
\hline & Question 3 & $\begin{array}{l}\text { How would you feel when you personally learn the knowledge of velocity, distance, } \\
\text { time to discuss with parents to choose the appropriate transportation to school? }\end{array}$ & Emotion & 12 & 4 \\
\hline & Question 4 & $\begin{array}{l}\text { How would you feel if you use the geometric knowledge to arrange tables and chairs } \\
\text { of your classrooms in a neat and beautiful order? }\end{array}$ & Emotion & 12 & 34 \\
\hline & Question 5 & $\begin{array}{l}\text { Would you be interested in comparing the similarities and differences in the shape of } \\
\text { objects in class and in your family with the shapes you learnt? }\end{array}$ & Emotion & 12 & 4 \\
\hline \multirow{3}{*}{ Family } & Question 6 & $\begin{array}{l}\text { Would you be interested in applying knowledge of percentage and mathematical } \\
\text { statistics to calculate savings on electricity, water, gas used in your family? }\end{array}$ & Emotion & $\begin{array}{lll}1 & 2\end{array}$ & 34 \\
\hline & Question 7 & Would you be interested in tracking money usage to save daily expenses? & motion & 12 & 134 \\
\hline & Question 8 & $\begin{array}{l}\text { From using the statistical knowledge and percentage to calculate electricity savings, } \\
\text { would you be interested in applying that knowledge to calculate water and gas } \\
\text { savings? }\end{array}$ & Emotion & 2 & 4 \\
\hline \multirow{2}{*}{ Society } & Question 9 & $\begin{array}{l}\text { Would you be interested in participating with people in communes, wards and villages } \\
\text { to apply mathematical knowledge of statistics, calculation, measurement ... to build } \\
\text { roads, sewers, parks, memorial houses? }\end{array}$ & Emotion & 2 & \\
\hline & Question 10 & $\begin{array}{l}\text { Would you be interested in using mathematical statistics and percentages to } \\
\text { investigate population, gender, employment, income levels ... in communes, wards or } \\
\text { villages? }\end{array}$ & Emotion & 12 & 34 \\
\hline
\end{tabular}

\section{Appendix C: Survey Questions for the Domain of Behavior for 5th Grade Students}

This survey seeks to investigate the correlation of Perception, Emotion and Behavior in teaching for the sustainable development of mathematical creativity of primary school students in Vietnam. Please circle the number that best represents your on-the-spot belief about each statement based on the corresponding scale below. 
Corresponding scale: Behavior; 1. Never, 2. Rarely, 3. Occasionally, 4. Regularly

\begin{tabular}{|c|c|c|c|c|c|c|c|}
\hline Factor & Question & Survey Question & Indicator & & & & \\
\hline \multirow{5}{*}{ School } & Question 1 & $\begin{array}{l}\text { Have you ever advised your classmates to eat, drink sensibly } \\
\text { and ensure nutrition to avoid malnutrition or obesity? }\end{array}$ & Behavior & 1 & 2 & 3 & 4 \\
\hline & Question 2 & $\begin{array}{l}\text { Have you ever discussed with your classmates how to measure } \\
\text { the appropriate seat for classmates with visual impairment? }\end{array}$ & Behavior & 1 & 2 & 3 & 4 \\
\hline & Question 3 & $\begin{array}{l}\text { Have you ever used your knowledge of speed, distance, and } \\
\text { time to choose an appropriate transportation to go to school } \\
\text { with your parents? }\end{array}$ & Behavior & 1 & 2 & 3 & 4 \\
\hline & Question 4 & $\begin{array}{l}\text { Have you ever used geometric knowledge to arrange tables and } \\
\text { chairs in your classrooms in a neat and beautiful order? }\end{array}$ & Behavior & 1 & 2 & 3 & 4 \\
\hline & Question 5 & $\begin{array}{l}\text { Have you ever shared with teachers and friends when you } \\
\text { realize the similarities and differences in the shape of objects in } \\
\text { the class and in your family with the shapes you learnt? }\end{array}$ & Behavior & 1 & 2 & 3 & 4 \\
\hline \multirow{3}{*}{ Family } & Question 6 & $\begin{array}{l}\text { Have you ever used knowledge of percentages and } \\
\text { mathematical statistics to calculate savings on electricity, water, } \\
\text { gas used in your family? }\end{array}$ & Behavior & 1 & 2 & 3 & 4 \\
\hline & Question 7 & $\begin{array}{l}\text { Have you ever recorded/tracked the use of money to save daily } \\
\text { expenses? }\end{array}$ & Behavior & 1 & 2 & 3 & 4 \\
\hline & Question 8 & $\begin{array}{l}\text { Have you ever used statistical knowledge and percentages to } \\
\text { calculate electricity savings as well as to calculate water and gas } \\
\text { savings? }\end{array}$ & Behavior & 1 & 2 & 3 & 4 \\
\hline \multirow[t]{2}{*}{ Society } & Question 9 & $\begin{array}{l}\text { Have you ever participated with people in communes, wards } \\
\text { and villages in using mathematical knowledge of statistics, } \\
\text { calculations, measurements to build roads, sewers, parks, } \\
\text { memorial houses ...? }\end{array}$ & Behavior & 1 & 2 & 3 & 4 \\
\hline & Question 10 & $\begin{array}{l}\text { Have you ever used mathematical statistics and percentages to } \\
\text { survey population, gender, employment, income ... in } \\
\text { communes, wards, villages or hamlets? }\end{array}$ & Behavior & 1 & 2 & 3 & 4 \\
\hline
\end{tabular}

